\title{
COMPARISON OF AIR DISTRIBUTION SYSTEMS IN ICE RINK ARENA VENTILATION
}

\author{
Agnieszka Stobiecka' ${ }^{1}$, Barbara Lipska ${ }^{2}$, Piotr Koper ${ }^{3}$ \\ Department of Heating, Ventilation and Dust Removal Technology, \\ Faculty of Energy and Environmental Engineering, Silesian University of Technology, Gliwice, Poland \\ E-mails: 1agnieszka.stobiecka@polsl.pl; ${ }^{2}$ barbara.m.lipska@polsl.pl;3piotr.koper@polsl.pl
}

\begin{abstract}
The paper presents the requirements and functions of ventilation in ice rink arenas and discusses difficulties and problems of ventilation in such objects. Particular attention has been paid to two types of inside used air distribution systems traditional-integrated and modern-separated where the functions of tribune ventilation and dehumidification of the air over the ice surface were separated. The flow of humid air and heat in the designed hall was modelled numerically using the ANSYS CFX code based on computational fluid dynamics (CFD) technique. Air distribution systems in the ice rink arena were compared based on the results of numerical calculations.
\end{abstract}

Keywords: ice rink, ventilation, air distribution, heat and moisture balance, numerical calculation CFD.

\section{Introduction}

The correctness of the design and work of the ventilation system depends largely on choosing the right concept of the air distribution system in the room. However, there are no explicit standards and guidelines for making such selection in ice rink arenas, which is the need for research on this subject. Today, a computational fluid dynamics (CFD) technique is the most common method used in this particular field. This is the numerical method used for solving a set of differential equations that describes fluid flow in relation with heat exchange, including ventilation airflow. One of the most popular programs based on this method is the ANSYS CFX code (www.ansys.com) applied in this study.

An ice rink arena is one of the places where the selection of air distribution systems poses difficulties and doubts (Fig. 1). We have to deal with an ice surface temperature of below $0^{\circ} \mathrm{C}$ and the presence of people, both spectators and skaters, whose requirements are different. An important problem that appears in such arenas is excess moisture leading to the condensation of water vapour contained in the air onto wall surfaces and the formation of fog above the ice surface.

Literature points out only few experimental and numerical studies about air distribution systems in indoor ice rinks, for example, an ice rink arena in Montreal (Bellache et al. 2005), Greater Boston (USA) (Yang et al. 2000), Gjøvik Olympic Cavern Hall in Norway (Ventilation... 1998) and Tsherepovets and Hodynka arenas in Russia (Lestinen et al. 2007).

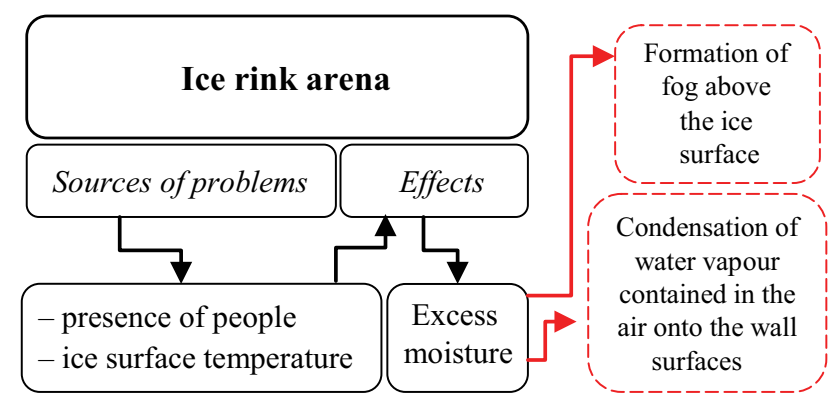

Fig. 1. Difficulties and doubts in the ice rink arena

However, these studies are concerned with a traditional air distribution system. The paper presents study results focused on comparing such air distribution system with an actually recommended one where airflow into the tribune is separated from airflow over the ice surface.

\section{Ventilation Requirements for Ice Rink Arenas}

A ventilation system in the ice rink arena should perform the following functions:

- ventilation/air heating function by maintaining adequate thermal and humidity conditions for the users of the ice rink arena,

- dehumidification function by removing excess moisture above the ice surface (Lipska et al. 2011). 
Requirements for indoor air parameters in the ice rink arena are as follows:

- indoor air temperature $-10 \div 12^{\circ} \mathrm{C}$ during a practice session and $12 \div 14^{\circ} \mathrm{C}$ during competitions;

- air temperature in the spectator area $-14 \div 15^{\circ} \mathrm{C}$;

- relative air humidity $-40 \div 65 \%$;

- air speed above the ice $-0.25 \mathrm{~m} / \mathrm{s}$.

The velocity value just above the ice surface is very important from the viewpoint of heat transfer between indoor air and the ice rink surface. When velocity is increased, heat transfer also increases. The ice surface gets warmer and, as a result, ice quality decreases and the cooling system under the ice rink needs to do more work (Sormunen et al. 2007).

Because of the danger of fog forming, it is important that ice surface temperature should be higher than dew point temperature in the room. Moreover, the inner surface of the ceiling is colder than the air below it. To prevent condensation, the temperature of the ceiling inner surface should also be higher than air dew point temperature in the room (Indoor ice ... 2007).

\section{Air Distribution Systems in Ice Rink Arenas}

For fulfilling the functions performed by ventilation, two types of air distribution systems are used in the hall:

1) traditional solution is the integrated system that performs both functions together;

2) modern solution is a separated system in which the ventilation/air heating function and dehumidification function are separated.

In the integrated system (Fig. 2), the ice rink with a tribune is a single zone. The supply of dry air is accomplished by long-throw jet nozzles placed directly under the roof, which helps with protecting from the condensation of water vapour. Exhaust is located in tribune space near the floor.

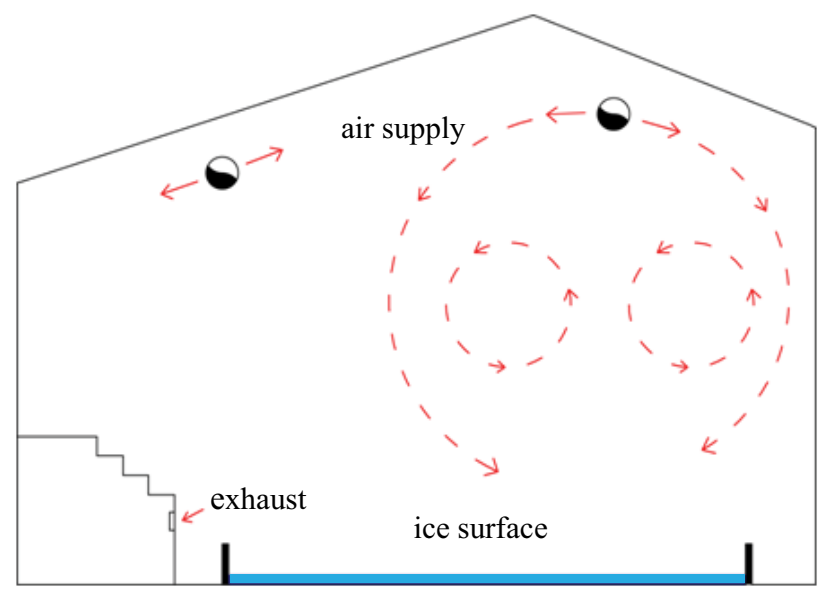

Fig. 2. An example of a solution to the integrated air distribution system in the ice rink (Lipska et al. 2011)

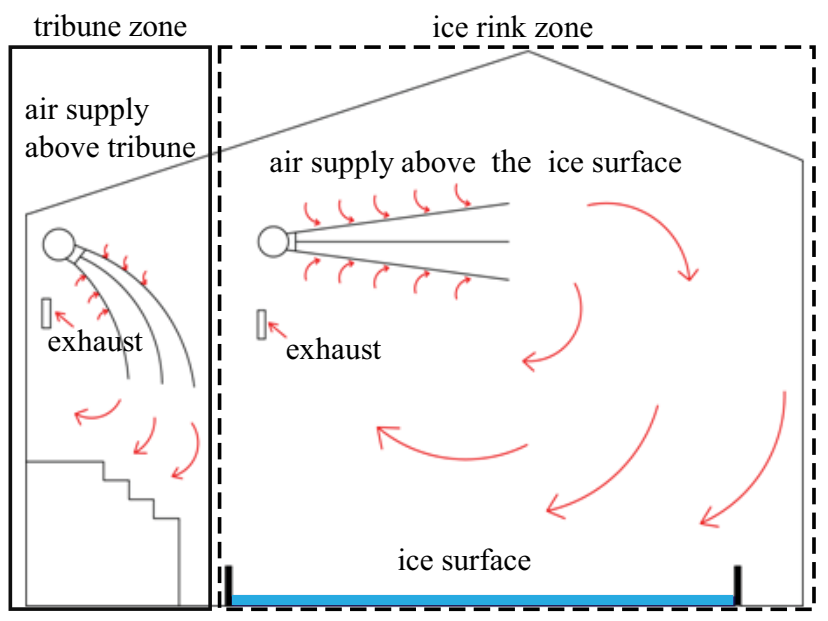

Fig. 3. An example of a solution to the separated air distribution system in the ice rink (Lipska et al. 2011)

This solution is preferred in places with small tribunes and small numbers of spectators, because it does not make sense to divide such place into two zones - it will be too expensive.

In the separated system (Fig. 3), the hall is divided into two zones: the tribune zone and the ice rink zone. Air supply is accomplished by long-throw jet nozzles located in the top part of the hall. The supply jets above the tribune are directed in such a way that the air spreads over the tribune zone and does not affect the ice surface. The parameters of this supplied air provide and maintain adequate thermal and humidity conditions for spectators. In the ice rink zone, the supplied air has been previously dried in a sorbent dehumidifier. Air volume flow rate amounts to $7 \div 10 \%$ of ventilation air volume flow rate. Supply jets from such nozzles are directed to the ice rink surface. Individual exhaust in each zone can be placed in an upper part of the hall.

\section{Description of the Investigated Object and Its Numerical Model}

The investigated object was a designed indoor ice rink located in Wadowice, Poland. The external dimensions of this object were as follows: length - $40 \mathrm{~m}$, width - $28 \mathrm{~m}$ and maximum height $-16 \mathrm{~m}$. The dimensions of the ice rink inside the object made $30 \mathrm{~m}$ by $20 \mathrm{~m}$. Internal partitions of the studied ice rink arena included a southern wall close to the tribune, an eastern wall and the rink floor. The remaining partitions were external. The northern wall was provided with windows. Internal heat sources contained a lighting system, spectators and skaters. However, the source of moisture was people only. 
A numerical model for the object of the study was worked out using the Ansys CFX code thus taking into account the overall dimensions and geometry of the designed hall. The ice rink, occupants, lighting system and ventilation system were modelled (Fig. 4). The XY symmetry plane was introduced because of the symmetry of this object.

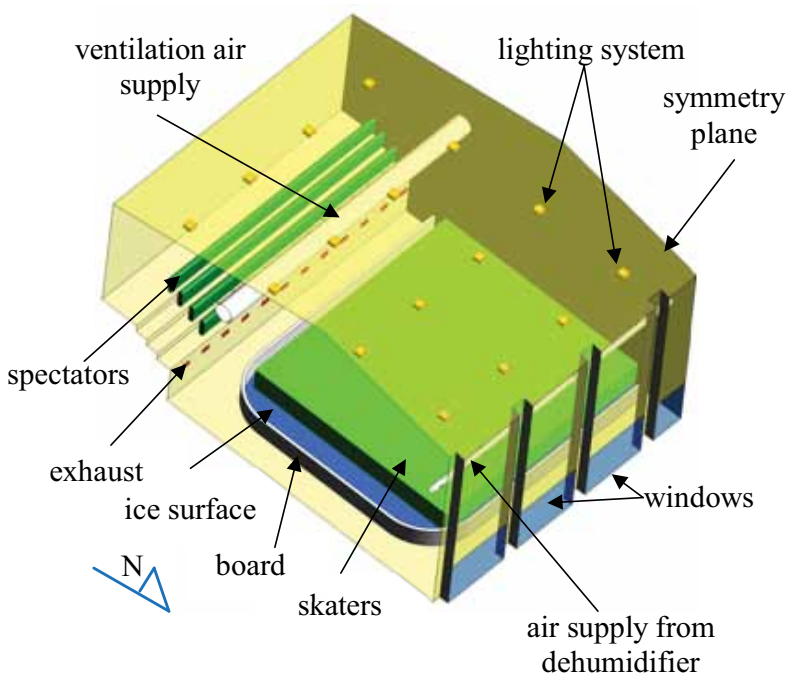

Fig. 4. The numerical model for a half of the rink hall (Lipska et al. 2011)

The ice sheet was modelled as a surface of constant temperature at $-3^{\circ} \mathrm{C}$ complying with standards (Refrigeration 2010) for a recreation ice rink, and moisture flux was set. The spectators were set as four rectangular sources of heat and moisture. The skaters were modelled by introducing a subdomain - a 3D region within a predefined domain that can be used for specifying values such as heat and moisture gains for volume occupied by people modelled in such a way. The lighting system was modelled as rectangular heat sources located in the top part of the hall. Long-throw jet nozzles were modelled as circular supply openings placed on ventilation supply ducts designed as circular ducts. Exhausts were set as rectangular grilles located in the first stage of the tribune. The model also included penetrating heat fluxes through internal and external partitions.

\section{Numerical Cases}

In case 1 , including the integrated air distribution system (Fig. 5a), air supply above tribune was accomplished by 16 long-throw jet nozzles with the diameter of $110 \mathrm{~mm}$. The nozzles were placed on a ventilation supply duct with the diameter of $1200 \mathrm{~mm}$ at a height of $13 \mathrm{~m}$ under the roof surface. The air supplied from the nozzles was directed at an angle of $40^{\circ}$. a)

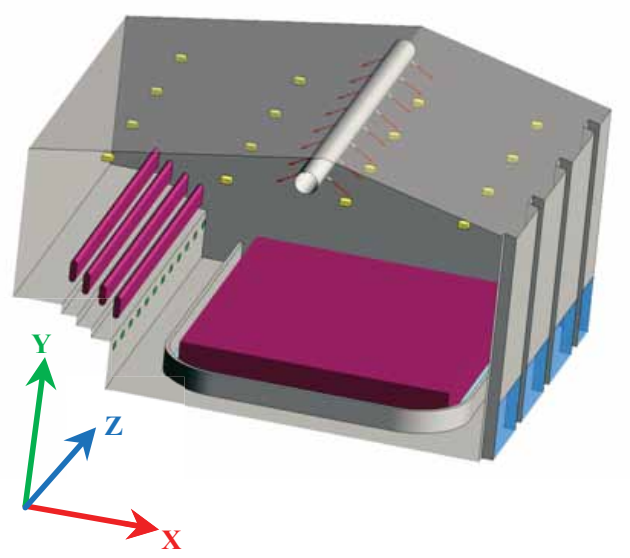

b)

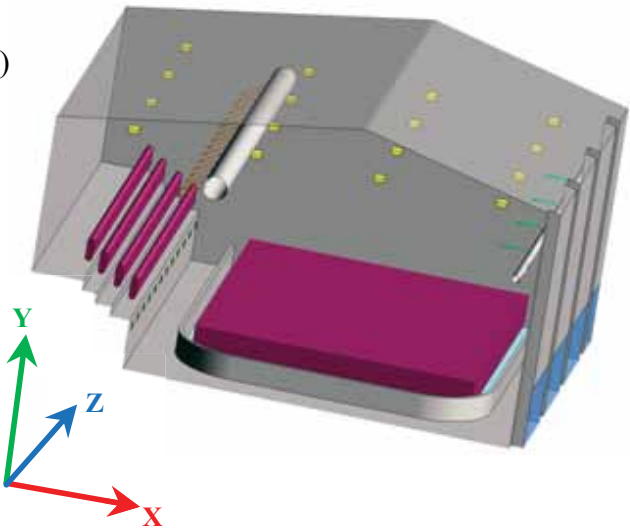

Fig. 5. The configuration of the rink hall a) case 1 ; b) case 2

The same set of the nozzles was used for the separated system in case 2 (Fig. 5b), and was localized at a height of $10 \mathrm{~m}$. Additionally, this system provided dehumidified air supply over the ice sheet by 4 long-throw jet nozzles with the diameter of $150 \mathrm{~mm}$ and located on a supply duct with the diameter of $400 \mathrm{~mm}$ at a height of $8.5 \mathrm{~m}$ at the northern wall. The air supplied from the nozzles was directed horizontally.

In both cases, there were 12 exhaust grilles with dimensions making $325 \times 525 \mathrm{~mm}$.

\section{Data Preparation}

Data preparation was based on design calculations for outdoor air at a temperature of $12^{\circ} \mathrm{C}$, the most disadvantaged from the viewpoint of heat and moisture balance. It was assumed to maintain the indoor air temperature of $12^{\circ} \mathrm{C}$ and relative air humidity of $40 \%$ in the hall.

The heat and moisture balance was made to determine boundary conditions and comprised

- gains of heat and moisture due to the presence of people - 162 skaters and 208 spectators, 
- gains of heat resulting from the lighting system consisting of 32 metal halide lamps,

- heat transfer through the walls,

- losses of heat and moisture from the ice sheet.

Based on this balance, the required air volume flow rate and parameters of supply air: ventilation and dehumidified additionally in a separated system, were calculated (Table). For example, the temperature of the supply air in both cases was $4^{\circ} \mathrm{C}$. Additionally, in the separated system, supply air from the dehumidifier was assumed as isothermal, with a temperature of $12^{\circ} \mathrm{C}$.

Table. Boundary conditions for the supply air

\begin{tabular}{|l|c|c|c|}
\hline \multirow{2}{*}{$\begin{array}{l}\text { Air } \\
\text { distribution } \\
\text { system }\end{array}$} & $\begin{array}{c}\text { Air mass } \\
\text { flow rate }\end{array}$ & $\begin{array}{c}\text { Air } \\
\text { temperature }\end{array}$ & Specific humidity \\
\cline { 2 - 4 } & $\mathrm{kg} / \mathrm{s}$ & ${ }^{\circ} \mathrm{C}$ & $\mathrm{kg}\left(\mathrm{H}_{2} \mathrm{O}\right) / \mathrm{kg}($ dry air $)$ \\
\hline $\begin{array}{l}\text { Integrated } \\
\text { system }\end{array}$ & 3.485 & 4 & 0.0025 \\
\hline $\begin{array}{l}\text { Separated } \\
\text { system }\end{array}$ & 3.485 & 4 & 0.0025 \\
\cline { 2 - 4 } & 0.3485 & 12 & 0.0030 \\
\hline
\end{tabular}

\section{Calculation Process}

Numerical calculations were carried out using the ANSYS CFX 12.1 code in a steady-state under three-dimensional and non-isothermal conditions. Simulations used the Shear Stress Transport turbulence model. Thermal radiation in the hall was performed by the Discrete Transfer Model. The discretization of model equations was carried out by the Finite Volume Method.

The applied unstructured discretization grid (Fig. 6) was composed mostly of tetrahedral elements and consisted of almost 10 million cells and about 2 million nodes in both cases. The calculations were carried out using the iteration method, and convergent solutions were obtained.
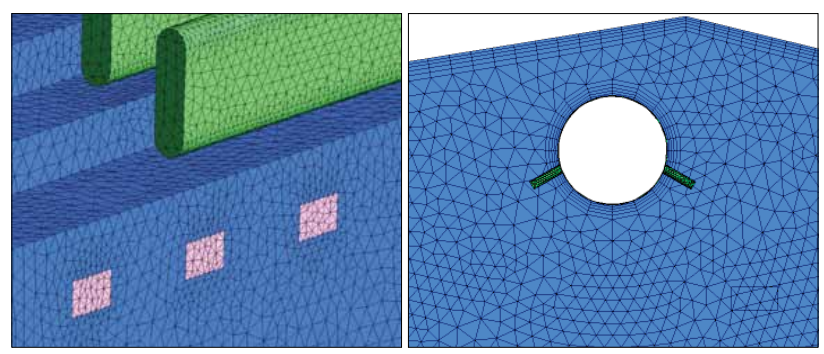

Fig. 6. Local refinement of the discretization grid around exhaust grilles (left) and the boundary layer around the supply duct and roof (right)

\section{Results and Discussion}

The results of numerical calculations were developed using the postprocessor of the CFX Ansys code and are shown in Fig. $7 \div 14$.

Fig. 7 displays a comparison of air speed maps in the ice rink arena in both cases the vertical plane and the horizontal plane located near the ice sheet. The mean indoor air speed at $10 \mathrm{~cm}$ above the ice surface was $0.32 \mathrm{~m} / \mathrm{s}$ in case 1 and $0.34 \mathrm{~m} / \mathrm{s}$ in case 2 . Also, in both cases, the permissible value of air speed $(\geq 0.25 \mathrm{~m} / \mathrm{s})$ was exceeded locally, although for a larger part of the cross-section in case 2 . This was a reason for the range of dehumidified air that covered almost the entire area of the ice surface. This also can be seen in the distribution of air speed in the vertical cross-section.

Fig. 8 shows a comparison of the pattern of air velocity vectors in vertical planes. The pattern of air velocity vectors in the areas of the supply air was analyzed. An air circulation region in the middle of the ice rink was created in the integrated system. The air supplied from the right row of the nozzles entered just above the surface of the ice creating secondary circulation. However, the air supplied from the left row of the nozzles in part got through under the roof surface, and in part directed to the centre of the ice rink where the air circulation region was created.

In the separated system, the whirls of humid air in the tribune zone could be observed: by the southern wall behind the last stage of the tribune and under the roof surface. However, dehumidified air escaped over the ice surface, and then, the air circulation zone in the middle of the ice rink was created. Circulating dehumidified air in part got through to the tribune zone and mixed with

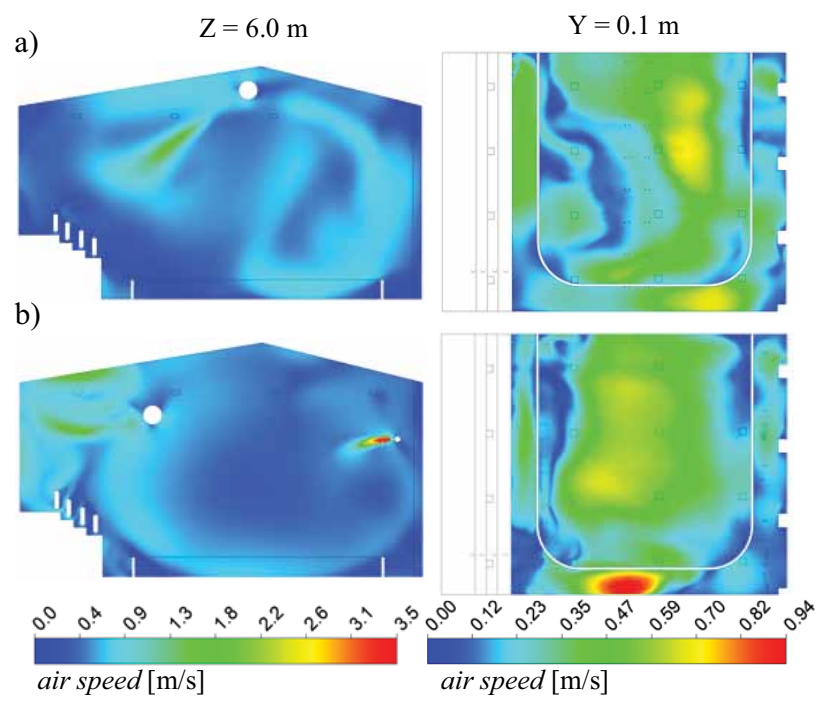

Fig. 7. A comparison of air speed maps in the ice rink arena a) case 1 ; b) case 2 
humid air, and in part was directed towards exhaust where the swirl of the air between the board and first stage of the tribune could be seen.

Fig. 9 presents a comparison of air temperature maps in vertical and horizontal planes located in the tribune zone. In case 1 , cold supply air did not affect thermal plumes above occupants. Behind the last stage of the tribune, the air was warmer than that in case 2 as a result of heat gains from spectators. Higher indoor air temperature in the area under the southern part of the roof surface also occurred. Indoor air temperature in tribune zone next to the southern wall amounted to about $13^{\circ} \mathrm{C}$ and $12^{\circ} \mathrm{C}$ in cases 1 and 2 respectively.

a)
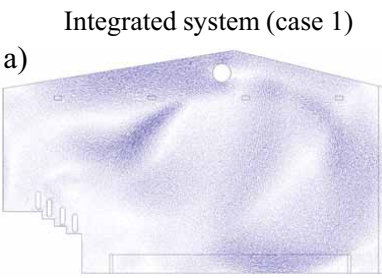

b)

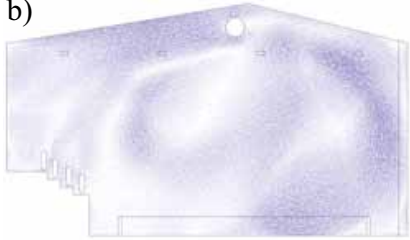

c)
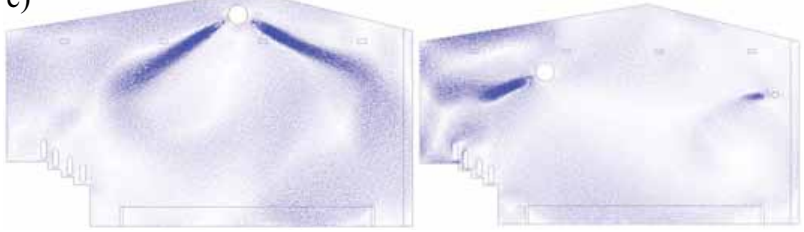

Fig. 8. A comparison of the pattern of the air velocity vector in the ice rink arena a) $Z=6.1 \mathrm{~m}$; b) $Z=8.7 \mathrm{~m}$; c) $Z=10.1 \mathrm{~m}$

a)

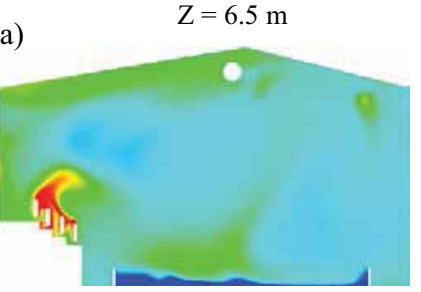

b)

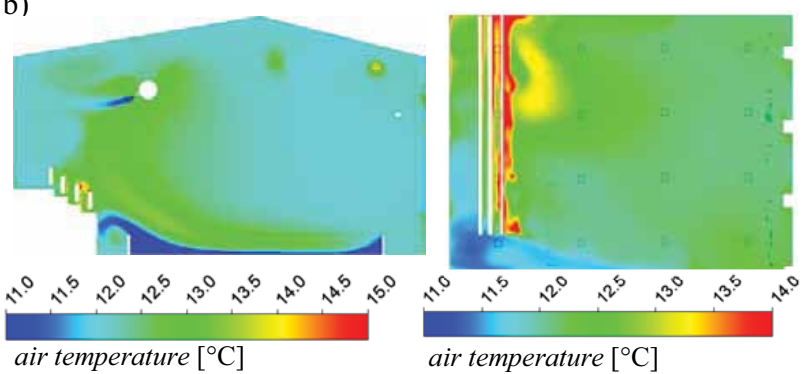

Fig. 9. A comparison of air temperature maps in the ice rink arena a) case 1 ; b) case 2

In the separated system, thermal plumes from skaters were pushed by supply jets from the dehumidifier towards exhaust and the tribune. In the integrated system, thermal plumes from the skaters were only partially directed towards exhaust. In both cases, a similar mean air temperature of about $12^{\circ} \mathrm{C}$ was obtained in the hall.

The mean air temperature at $10 \mathrm{~cm}$ above the ice surface was $10.8^{\circ} \mathrm{C}$ in case 1 and $10.9^{\circ} \mathrm{C}$ in case 2 . The air temperature did not exceed $12.8^{\circ} \mathrm{C}$ in both cases (Fig. 10).

Fig. 11 shows isotherm maps on the inner surface of the roof. The mean temperature of the roof surface was $12.5^{\circ} \mathrm{C}$ and $12.1^{\circ} \mathrm{C}$ in cases 1 and 2 respectively. The mean temperature of the roof surface in case 1 was slightly higher than that in case 2 due to the intake of warmer air under the roof surface and due to a greater impact of lighting. In both cases, the roof surface has high enough temperature, higher than the dew point of indoor air below it amounted to about $-4 \div-2^{\circ} \mathrm{C}$, to prevent the condensation of water vapour.

Fig. 12 displays a comparison of the maps of relative air humidity in horizontal and vertical planes. Relative humidity should not exceed $38 \%$ to prevent fogging at the ice level if the mean air temperature above the ice surface is about $11^{\circ} \mathrm{C}$ and the temperature of the ice surface is $-3^{\circ} \mathrm{C}$. The mean relative air humidity at $10 \mathrm{~cm}$ above the ice surface was about $32 \%$ in both cases, which means there was not a risk of fog forming above the ice surface.

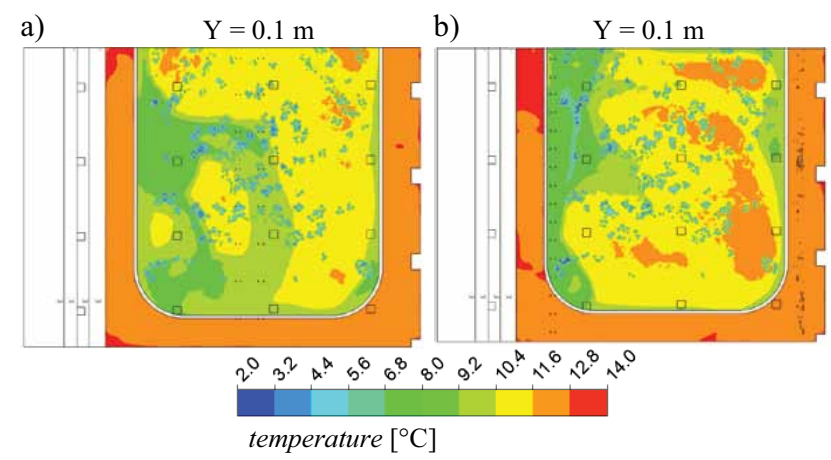

Fig. 10. A comparison of air isotherm maps in the ice rink arena a) case 1, b) case 2

a)

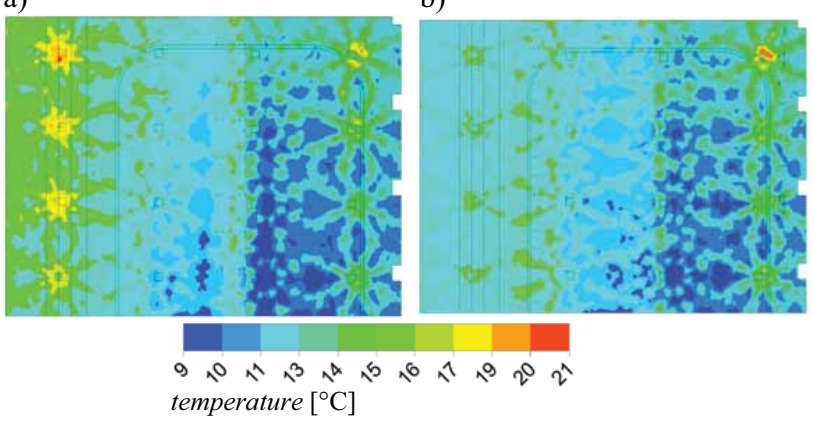

Fig. 11. A comparison of isotherm maps on the inner roof surface a) case 1 ; b) case 2 


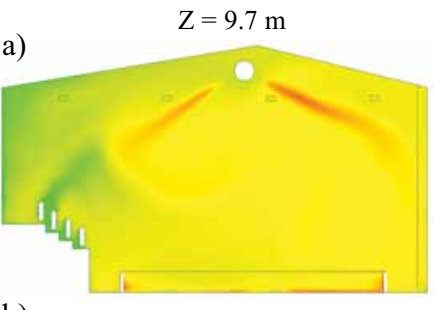

b)
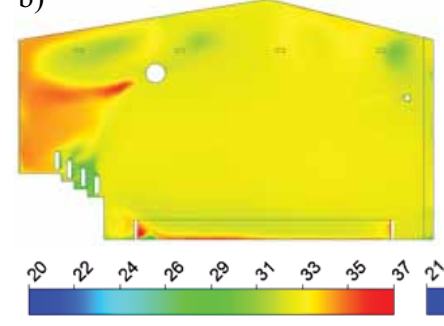

relative air humidity $[\%]$
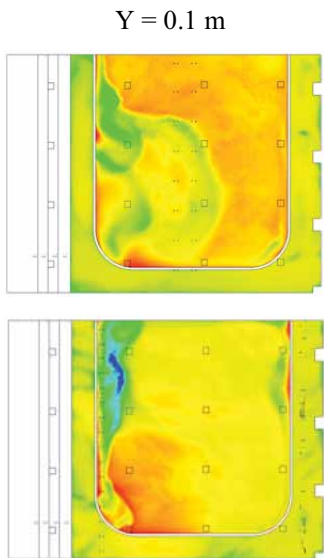

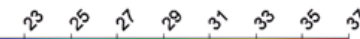

relative air humidity $[\%]$

Fig. 12. A comparison of relative air humidity maps in the ice rink arena a) case 1 ; b) case 2

a)

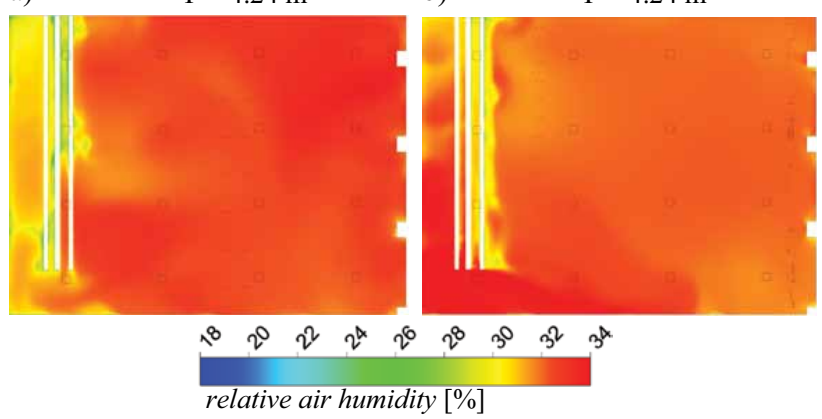

Fig. 13. A comparison of relative air humidity maps in the tribune zone a) case 1 ; b) case 2

Moreover, the air supplied from the dehumidifier in the separated system only caused a local reduction in the relative air humidity value, but on a larger part of the crosssection than the supplied air in case 1 .

Relative air humidity in the tribune zone was in the range of $30 \div 32 \%$ and $31 \div 34 \%$ in cases 1 and 2 respectively. The maximum value of relative humidity at $4.24 \mathrm{~m}$ above the ice surface was about $34 \%$ in both cases (Fig. 13).

\section{Conclusions}

1. Both air distribution systems were able to maintain the required indoor air temperature; however, a lower value of relative humidity than the designed one was obtained. Due to the maintenance of adequate thermal and humidity conditions, the integrated system was less effective, because supply air jets did not affect thermal plumes above the occupants, in particular the spectators.

2. In the separated system, we can expect larger areas where air speed will exceed the permissible value above the ice surface.

3. The risk of fogging above the ice surface and the danger of condensation of water vapour on the roof surface did not appear in any studied air distribution systems.

4. Conclusions from the comparative analysis are based only on the results of numerical studies and therefore require experimental validation under conditions of an actual object, which should be the subject of further research.

\section{References}

Bellache, O.; Ouzzane, M.; Galanis, N. 2005. Numerical prediction of ventilation patterns and thermal processes in ice rinks, Building and Environment 40: 417-426. http://dx.doi.org/10.1016/j.buildenv.2004.08.004

Indoor ice rink dehumidification. 2007 Desert Aire, Application Note 13. Rev. 10.

Lestinen, S.; Laine, T.; Sundman, T. 2007. Scoring an HVAC global for hockey spectators. CFD is used to design ventilation systems for sports arenas, ANSYS Adventage I/1.

Lipska, B.; Koper, P.; Jopert, K..; Trzeciakiewicz, Z. 2011: Badania numeryczne rozdziału powietrza wentylacyjnego $\mathrm{w}$ hali krytego lodowiska [Numerical study of air distribution in indoor ice rink arena], Cieptownictwo, Ogrzewnictwo $i$ Wentylacja 42(10): 431-437 (in Polish).

Refrigeration. 2010 ASHRAE Handbook, 1791 Tullie Circle, N.E. Atlanta, GA 303292010.

Sormunen, P.; Sundman, T.; Lestinen, S. 2007. The design challenges of multipurpose Arenas, in Proceedings of Climate Well Being Indoors. Finland.

Stobiecka, A. 2012. Wplyw różnych czynników na warunki panujace $w$ halach lodowisk [Influence of various factors affecting ice rink arenas conditions]. MA Thesis, Silesian University of Technology, Gliwice (in Polish).

Ventilation of large space in buildings. Part 3 - Analysis and prediction techniques. 1998 Report IEA Annex 26.

Yang, C.; Demokritou, P.; Chen, Q.; Spengler, J. 2000. Ventilation and air quality in indoor ice skating arenas, ASHRAE Transactions 106, Pt. 2. 